\title{
Aplikasi Wind Powered Composter Di Kawasan Pesisir Kelurahan Cambayya Kota Makassar
}

\section{Application of Wind Powered Composter in the Coastal Area of Cambayya Village, Makassar City}

\author{
${ }^{1}$ Ramdiana, ${ }^{2}$ Nani Anggraini, ${ }^{3}$ Sattar Yunus, ${ }^{4}$ Hadiratul Kudsiah \\ 1Jurusan Teknik Pengembangan Wilayah dan Kota, Fakultas Teknik, Universitas \\ Muhammadiyah Parepare \\ ${ }^{2}$ Jurusan Teknik Lingkungan, Fakultas Teknik, Universitas Bosowa, Makassar \\ 3Jurusan Teknik Mesin, Fakultas Teknik, Universitas Muslim Indonesia, Makassar \\ ${ }^{4}$ Departemen Perikanan, Fakultas Ilmu Kelautan dan Perikanan, Universitas Hasanuddin, \\ Makassar
}

Korespondensi: Ramdiana, ramdiana.uts@gmail.com

Naskah Diterima: 16 September 2019. Disetujui: 26 Januari 2020. Disetujui Publikasi: 29 Januari 2020

\begin{abstract}
Cambayya Village is one of the coastal areas of Makassar City which has a very complex waste condition, which is garbage from the people who live and carry out activities in the coastal area, garbage sent from land area that flows from rivers or gutters that flow into the coast. The Community Service Program aims to conduct activities in the form of training, practice and assistance in processing organic waste into compost using Wind Powered Composter technology located in the RT A community group of Cambayya Village. The problem by partners is the large amount of garbage generated in the coastal settlements of Cambayya Village, residents do not yet know how to process organic waste, and there is no practical application of renewable technology that is acceptable to the community in environmental management. The technology applied is Wind Powered Composter Technology which is an organic waste processing technology using wind power as an energy source to produce compost that can be useful for greening and economic value. This method is contained from a few stages: Preparation stage, namely processing permits, socializing activities to partners, and preparing training materials, Implementation stage conducting motivational training in processing waste, training on organic waste sorting, making composter equipment, making use of SOP training, the practice of composting, harvest compost and compost packaging, The evaluation stage by providing assistance and periodic checking of the composting process. The results of the implementation of this activity are the reduction in the volume of $60 \mathrm{~kg}$ of organic waste in each composting process, increased knowledge of citizens about organic waste processing, and the application of appropriate technology in coastal areas.
\end{abstract}

Keywords: Organic waste, composter, wind powered

Abstrak. Kelurahan Cambayya merupakan salah satu wilayah pesisir Kota Makassar yang memiliki kondisi sampah yang sangat kompleks yaitu sampah dari masyarakat yang tinggal dan melakukan aktivitas di wilayah pesisir, sampah kiriman dari wilayah daratan atas yang mengalir dari sungai atau selokan yang bermuara ke pesisir. Adanya program Pengabdian kepada Masyarakat ini bertujuan melakukan kegiatan dalam bentuk pelatihan, praktek dan pendampingan dalam pengolahan sampah organik menjadi kompos dengan menggunakan teknologi Wind Powered Composter yang berlokasi di kelompok warga RT A Kelurahan Cambayya. Masalah yang dihadapi mitra adalah banyaknya timbulan sampah yang dihasilkan di permukiman pesisir Kelurahan Cambayya, warga belum mengetahui cara mengolah sampah organik, dan belum ada penerapan teknologi terbarukan yang praktis dan mampu diterima masyarakat dalam pengelolaan lingkungan. Teknologi yang diterapkan adalah Teknologi Wind Powered Composter yang merupakan teknologi pengolahan sampah organik menggunakan Jurnal Panrita Abdi, 2020, Volume 4, Issue 1.

http://journal.unhas.ac.id/index.php/panritaabdi 
tenaga angin sebagai sumber energi menghasilkan kompos yang dapat bermanfaat untuk penghijauan dan bernilai ekonomi. Metode kegiatan ini diantaranya: Tahap persiapan yaitu pengurusan surat izin, sosialisasi kegiatan ke mitra, dan persiapan materi pelatihan, Tahap pelaksanaan melakukan pelatihan motivasi dalam mengolah sampah, pelatihan pemilahan sampah organik, pembuatan alat komposter, pelatihan SOP penggunaan alat, praktek pembuatan kompos, panen kompos, dan pengemasan kompos, Tahap evaluasi dengan melakukan pendampingan dan pengecekan berkala terhadap proses pembuatan kompos. Hasil pelaksanaan kegiatan ini adalah berkurangnya volume sampah organik maksimal $60 \mathrm{~kg}$ dalam setiap proses pengomposan, meningkatnya pengetahuan warga tentang pengolahan sampah organik, dan telah diterapkannya teknologi tepat guna di kawasan pesisir.

Kata Kunci: Sampah organik, komposter, tenaga Angin

\section{Pendahuluan}

Kota Makassar sebagai salah satu kota besar di Indonesia juga tidak terlepas dari masalah sampah. Hal ini tidak terlepas dari peningkatan laju pertumbuhan penduduk di Kota Makassar. Jumlah penduduk Kota Makassar pada tahun 2016 mencapai 1.658.503 jiwa, sedangkan ditahun 2017 angka ini mengalami peningkatan yang signifikan mencapai 1.769.920 jiwa (BPS, 2017). Pertambahan jumlah penduduk ini berkolerasi langsung terhadap sampah yang dihasilkan. Semakin tinggi jumlah penduduk suatu daerah maka sampah yang dihasilkan juga semakin banyak. Pada umumnya komposisi sampah di Kota Makassar berasal dari sampah organik yang berasal dari sampah rumah tangga yaitu $67,14 \%$ dari total sampah (Zubari, dkk., 2011).

Kelurahan Cambayya merupakan salah satu kawasan padat penduduk yang terletak didaerah pesisir Kota Makassar. Tercatat pada tahun 2017 jumlah penduduk Kelurahan Cambayya mencapai 5943 jiwa yang hidup dilahan seluas 5,3 hektar. Sebagai kawasan pesisir yang padat penduduk Kelurahan Cambayya telah mengalami penurunan kualitas lingkungan. Bentuk penurunan kualitas lingkungan di Kelurahan Cambayya adalah banyaknya timbulan sampah di sekitar wilayah permukiman pesisir Cambayya, hal ini juga tidak lepas dari rendahnya kapasitas SDM dengan tingkat pendidikan penduduk paling banyak adalah SD sebanyak 2425 orang (40,8\%). Sebanyak 454 KK (31,3\%) masih membuang sampah disembarang tempat terutama dilaut. Kondisi jalan di permukiman terbuat dari jembatan kayu dengan lebar rata-rata 1,2 meter. Padatnya permukiman dan sulitnya akses menyebabkan proses pengumpulan sampah di wilayah ini yang cukup sulit.

Mitra kegiatan pengabdian ini adalah kelompok warga RT A di Kelurahan Cambayya. Kondisi permukiman di lokasi mitra terdiri dari 119 KK yang terbagi menjadi $57 \mathrm{KK}$ rumah permanen dan rumah panggung kayu $62 \mathrm{KK}$. Dari data hasil penelitian sebelumnya, diperoleh rata-rata timbulan sampah yang dihasilkan warga di kelurahan cambayya adalah sebanyak $1,81 \mathrm{~kg} / \mathrm{kk} / \mathrm{hr}$ dengan komposisi $42 \%$ diantaranya sampah organik dan 58\% sampah anorganik (Anggraini, dkk., 2018). Kondisi akses jalan yang sulit dijangkau oleh mobil pengangkut sampah menyebabkan banyaknya timbulan sampah yang tidak dapat diangkut dan sebagian di buang di laut.

Berdasarkan analisis situasi di atas, maka permasalahan yang dihadapi mitra adalah (1) banyaknya timbulan sampah yang dihasilkan di permukiman pesisir Kelurahan Cambayya yang tidak diolah dan sebagian di buang ke laut, (2) warga belum mengetahui cara mengolah sampah organik, (3) belum ada penerapan teknologi terbarukan yang praktis dalam pengolahan sampah organik.

Pengomposan dapat menjadi salah satu alternatif dalam mengurangi volume sampah organik. Berdasarkan penelitian yang dilakukan Djuwendah (2004), tentang keragaman sosial ekonomi usaha daur ulang dan pengomposan sampah di Bandung, menyimpulkan bahwa usaha pengkomposan sampah organik mencapai produksi kompos 19.909,86 Kg dengan potensi pendapatan Rp 20.652.419. Usaha 
daur ulang dan pengkomposan sampah dapat menurunkan volume sampah yang harus dikelola sekitar 41,65\% atau 3062,64 $\mathrm{m}^{3}$ per hari. Penelitian lain yang dilakukan oleh BPPT (http://groups.yahoo.com) melalui Pusat Pengkajian dan Penerapan Teknologi Lingkungan mengembangkan konsep yang diberi nama Zero Waste. Konsep ini salah satunya menyebutkan bahwa, dengan penerapan teknologi secara terpadu akan berkembang pula satu model pengelolaan sampah dalam bentuk industri kecil daur ulang yang dilakukan masyarakat sebagai mitra pemerintah daerah dalam pelayanan kebersihan.

Kegiatan Pengabdian kepada Masyarakat ini menggunakan teknologi tepat guna pengolah sampah organik model komposter yang menggunakan tenaga angin sebagai sumber energi. Teknologi ini dilengkapi kincir sebagai penggerak, pencacah sampah, dan pengontrol suhu. Teknologi ini adalah teknologi terbarukan dan belum pernah dibuat sebelumnya. Teknologi yang diterapkan di beberapa kota di indonesia masih menggunakan listrik sebagai sumber energi. Dalam penelitian yang dilakukan oleh Mutaqin \& Totok (2010) pengolahan sampah menggunakan komposter elektrik mengeluarkan biaya operasional sebesar Rp 1.280 .000 setiap bulan. Oleh karena itu teknologi yang diterapkan ini tentu memiliki keunggulan dapat menghemat biaya operasional karena menggunakan tenaga angin sebagai sumber energi. Dari segi waktu pengomposan untuk Wind Powered Composter ini lebih cepat yaitu 7-9 hari dibandingkan metode komposter individu/takakura. Menurut Lando, dkk., (2019) waktu pengomposan metode takakura memerlukan waktu $2-3$ bulan dalam sekali pembuatan kompos.

Tujuan dari kegiatan ini adalah melakukan pelatihan, praktek dan pendampingan pada kelompok warga pesisir Kelurahan Cambayya dalam pengolahan sampah organik, memberikan pelatihan motiviasi dalam mengolah sampah dan pelatihan pemilahan sampah organik serta praktek dalam pengolahan sampah dengan menggunakan alat Wind Powered Composter. Penerapan teknologi ini diharapkan dapat mengurangi volume sampah di permukiman warga Kelurahan Cambayya, selain itu dapat memberikan pengetahuan dan keterampilan pada mitra dalam dalam mengolah sampah organik dan menghasilkan kompos sehingga menjadi sesuatu yang bermanfaat dan bernilai jual.

\section{Metode Pelaksanaan}

Tempat dan Waktu. Kegiatan ini merupakan kegiatan Pengabdian kepada Masyarakat Program Kemitraan Masyarakat (PKM). Tempat pelaksanaan Program Kemitraan Masyarakat yaitu permukiman warga RT A di Kawasan Pesisir Cambayya Kecamatan Ujung Tanah Kota Makassar Provinsi Sulawesi Selatan. Waktu pelaksanaan kegiatan ini dari 14 April sampai 11 Oktober 2019. Kegiatan pelatihan dan, praktek, dan pendampingan ini terbagi atas 3 tahap rangkaian kegiatan yaitu Tahap I persiapan mulai tanggal 24 April 2019, Tahap II pelaksanaan mulai tanggal 23 Juni 2019 sampai 29 September 2019 dan Tahap III pendampingan pada tanggal 5 Oktober 2019.

Khalayak Sasaran. Sasaran pelaksanaan program kemitraan ini yaitu pada permukiman warga Kelurahan Cambayya pada kelompok ibu-ibu RT A yang berjumlah 20 orang. Diharapkan warga yang terlibat langsung dalam kegiatan ini dapat menyerap ilmu yang telah diberikan selama proses pelatihan dan praktek pengolahan sampah.

Metode Pengabdian. Metode yang digunakan dalam Penerapan Teknologi komposter pada Program Kemitraan Masyarakat adalah melalui beberapa tahapan yaitu :

Tahap persiapan terdiri dari beberapa kegiatan :

1. Pengurusan surat izin kegiatan pengabdian di Kelurahan Cambayya. 
2. Audiensi ke pihak mitra yaitu warga RT A kelurahan Cambayya untuk mengkoordinasikan kegiatan yang akan dilaksanakan

3. Pembuatan materi pelatihan

Tahap pelaksanaan yaitu terdiri dari beberapa kegiatan :

1. Pelatihan motivasi pengolahan sampah

2. Pelatihan pemilahan sampah organik menumbuhkan pengetahuan dan motivasi masyarakat dalam memilah sampah organik yang akan diolah menjadi kompos.

3. Pembuatan alat/teknologi Wind Powered Composter

4. Pelatihan SOP penggunaan alat dan Praktek pembuatan kompos menggunakan alat Wind Powered Composter

Praktek pembuatan kompos diawali dengan mengumpulkan sampah organik yang dilakukan oleh warga ke dalam kantong plastik yang sudah diberikan. Jumlah sampah yang masuk berasal dari 20 rumah tangga yang telah dipilah dengan berat sekitar $48 \mathrm{~kg}$.

Adapun SOP pengaplikasian teknologi pengomposan

a. Memasukkan sampah organik berupa sisa makanan, sisa ikan dan duri ikan, kulit buah-buahan, potongan sayuran, dll maksimal sebanyak $60 \mathrm{Kg}$ kedalam komposter.

b. Menambahkan bahan kaya karbon berupa sekam gergaji.

c. Menambahkan kompos jadi sebagai starter.

d. Memasukkan sampah kedalam crusher (pencacah)

e. Memberikan larutan EM4 sebanyak 1 cup ( setara 0,5 permil dari bahan sampah organik $60 \mathrm{~kg}$ ) dan menyemprtokan larutan aktivator kompos tersebut secukupnya ke semua bagian sampah sampai merata dan lembab, dan aduk sampah selama 10 menit.

f. Setelah 3 sampai 4 hari kemudian, akan terjadi reaksi panas. Jika suhu melebihi 55 derajat Celcius, akan dilakukan penggembosan udara ( oksigen) dengan cara memutar rotary aerasi yang ada disisi kanan alat mesin ini.

g. Reaksi dekomposisi biasanya akan terjadi pada hari ke 3 sampai ke 5, dengan tanda- tanda tabung komposter panas (hingga 70 derajat Celcius) serta keluarnya sedikit uap, lakukan penggembosan udara setiap kali suhu udara melewati 55 derajat celcius ( suatu kondisi mesofilik bagi kerja optimal bakteri pengurai) .

h. Pada hari ke 5 sampai ke 7 jika suhunya sudah di bawah 30 derajat Celcius atau dianggap sudah dingin, keluarkan bahan kompos dari dalam komposter dan simpan di tempat teduh tapi berangin serta tutup dengan karung kemasan (PE) untuk diangin-anginkan atau dapat juga di masukan dalam karung PE dan ditumpuk ditempat yang teduh.

i. Sekitar tujuh (7) hari kemudian, bahan kompos akan kering dan gembur.

j. Ayak hingga terpisahkan antara butir lolos mess 100 dengan bahan ukuran besar.

k. Gundukan butiran kecil bisa masukan kedalam kemasan, dan sisa yang tidak terayak bisa dimasukkan kembali ke prose pembuatan selanjutnya sebagai starter.

5. Panen Kompos

6. Pengemasan kompos menggunakan plastik yang telah diberi label.

Tahap evaluasi dan pendampingan dengan melakukan pendampingan dan pengecekan berkala terhadap proses pembuatan kompos.

Indikator Keberhasilan. Indikator untuk mengukur keberhasilan pelatihan SDM di permukiman Cambayya dengan cara memberikan kuis di akhir pelatihan untuk mengetahui adanya peningkatan pengetahuan masyarakat. Tim memberikan beberapa pertanyaan terkait materi yang diberikan. Keberihasilan kegiatan ini 
dinilai dari persentasi warga yang telah memahami pemilahan sampah organik dan telah terampil dalam menggunakan alat sesuai SOP yang benar. Menurut Kudsiah, dkk. (2018) menyatakan bahwa kriteria keberhasilan apabila $\geq 60 \%$ khalayak sasaran mau dan mampu menerapkan pengetahuan, keterampilan dan percontohan yang diberikan.

Metode Evaluasi. Metode evaluasi dilakukan dengan cara: (1) melakukan pengecekan proses pembuatan kompos yang dilakukan warga sesuai dengan SOP penggunaan alat, (2) pendampingan secara berkala lama waktu pengomposan dan pengecekan pada kompos yang dihasilkan sesuai dengan standar sari segi bau dan warna, (3) pendampingan pengemasan kompos dan pemanfaatan kompos untuk tanaman maupun dijual kepada pihak yang membutuhkan. Menurut Rifa'i dkk (2017) menyatakan bahwa evaluasi terhadap program juga dilakukan dengan mengukur keberhasilan sesuai dengan indikator yang ditetapkan. Evaluasi kegiatan dilakukan sesuai dengan indikator keberhasilan dengan cara melihat hasil capaian dan melihat secara langsung berapa besar penguasaan para warga kelompok ibu-ibu cambayya mengenai pengolahan sampah organik menggunakan teknologi Wind Powered Composter.

\section{Hasil dan Pembahasan}

\section{A. Persiapan Kegiatan}

Pelaksanaan Pengabdian kepada Masyarakat ini diawali dengan tahapan persiapan yang terdiri dari beberapa kegiatan :

1. Pengurusan surat izin kegiatan pengabdian di Kelurahan Cambayya.

2. Audiensi ke pihak mitra yaitu warga RT A kelurahan Cambayya untuk mengkoordinasikan kegiatan yang akan dilaksanakan (Gambar 1).

3. Pembuatan materi pelatihan.
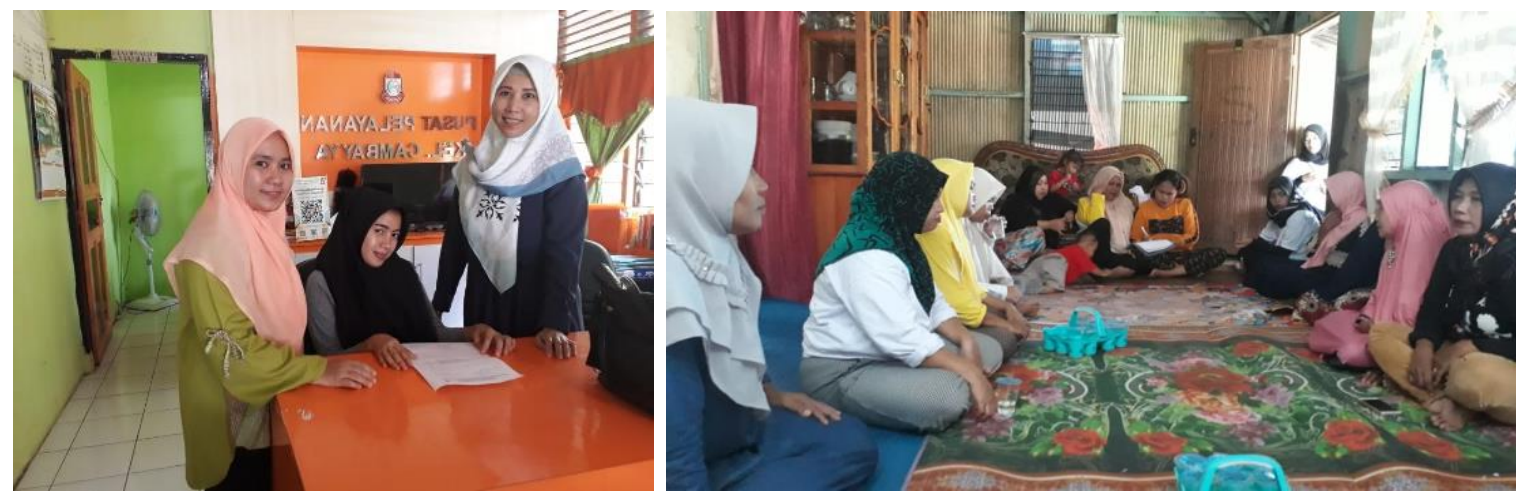

Gambar 1. Pengurusan izin dan audiensi di warga permukiman cambaya

\section{B. Pelatihan dan Praktek}

Pada tahap ini dilakukan beberapa kegiatan yaitu :

\section{Pelatihan Motivasi dalam Mengolah Sampah}

Kegiatan ini merupakan tahapan awal dari proses penyuluhan yang dilaksanakan untuk meningkatkan kemampuan mengelola lingkungannya utamanya dalam hal persampahan. Menurut anggraini (2010), penguasaan pengetahuan dan keterampilan untuk meningkatkan kemampuan dalam arti soft skill. Kegiatan penyuluhan tahap pertama ini berupa pemberian materi mengenai pentingnya mengolah sampah di wilayah pesisir sebagai area hunian yang mereka tempati saat ini. Kegiatan ini mencoba membangun antusiasme warga dan rasa tanggung jawab dalam mengelola lingkungannya. Anggota mitra yang seluruhnya adalah ibu rumah tangga dengan tingkat pendidikan dan ekonomi menengah kebawah harus di pacu semangatnya. Mereka diberikan informasi mengenai dampak makro dan mikro dari 
kondisi persampahan yang terjadi di wilayah permukiman pesisir Cambayya dan manfaat sosial dan ekonomi yang dapat diperoleh jika mereka mampu mengelola sampah yang mereka hasilkan (Gambar 2).

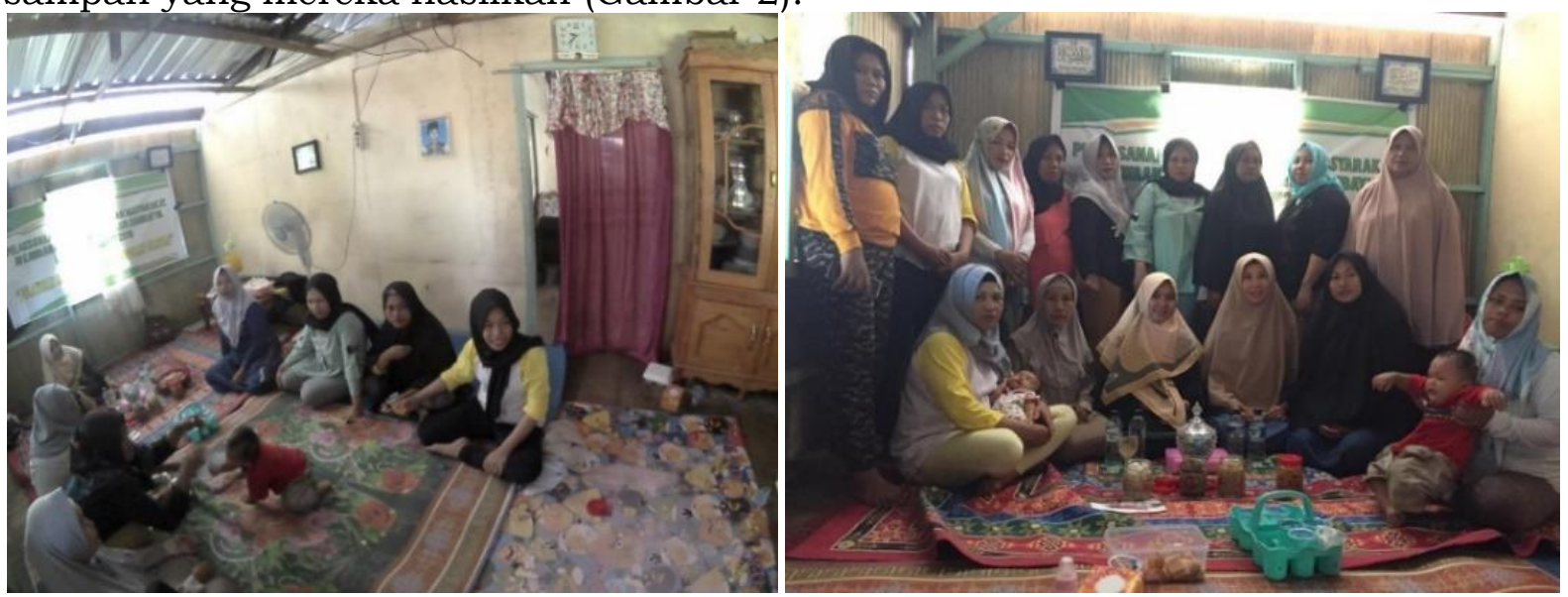

Gambar 2. Suasana pelatihan motivasi dalam mengolah sampah

\section{Pelatihan Pemilahan Sampah Organik}

Pelatihan lanjutan bagi masyarakat adalah pemilahan sampah organik (Gambar 3). Pelatihan ini bertujuan untuk peningkatan kemampuan SDM dengan menumbuhkan pengetahuan dan motivasi masyarakat dalam memilah sampah organik yang akan diolah menjadi kompos. Kegiatan pelatihan ini sangat penting agar masyarakat bersemangat untuk memilah sampah organik yang akan mereka olah dengan menggunakan alat komposter. Kegiatan ini diakhiri dengan memberikan kuis menarik dan interaktir untuk menguji kemampuan masyarakat mitra dalam menerima materi penyuluhan. Kegiatan berlangsung lancar dengan penuh antusiasme dari masyarakat mitra yang diharapkan dapat memberikan harapan besar bahwa tahapan berikutnya dapat berlangsung dengan baik.

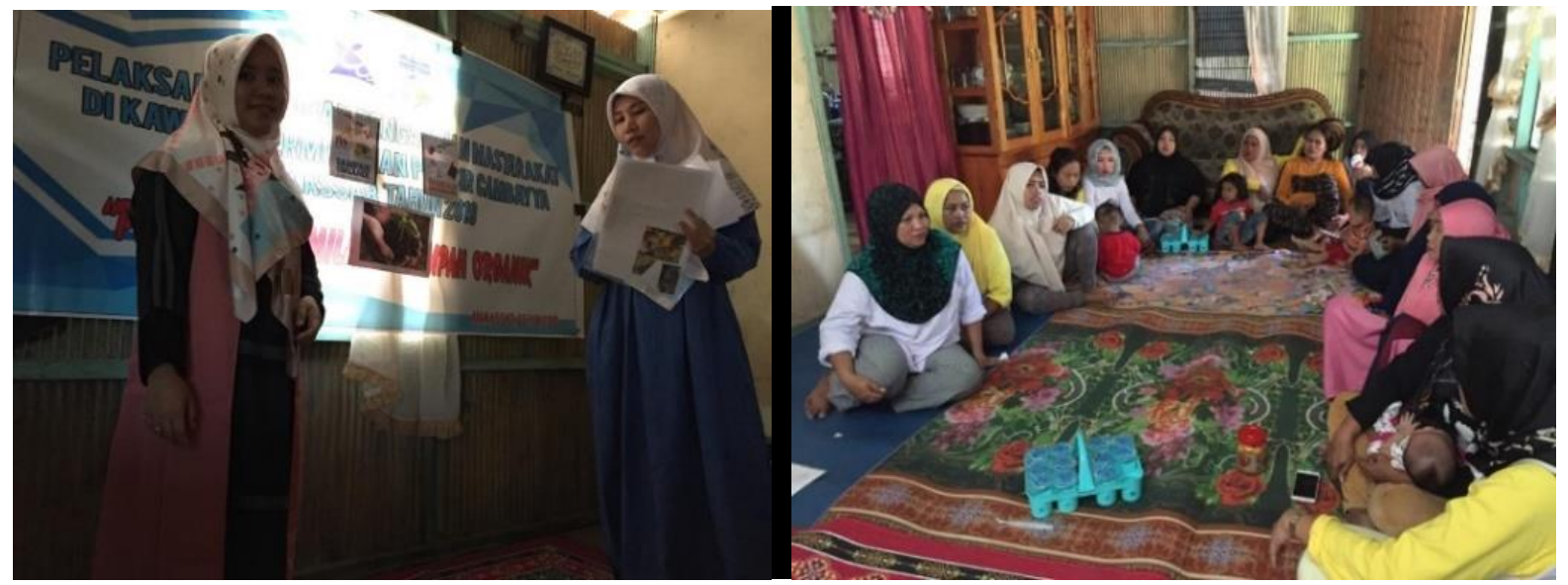

Gambar 3. Pemberian Materi Pelatihan Pemilahan Sampah Organik

\section{Pembuatan Alat Wind Powered Composter}

Rangka mesin terbuat dari besi siku dengan dimensi 40 x $40 \mathrm{~mm}$. Mesin Tabung Komposter terbuat dari bahan stainless dengan dimensi Tinggi $=91,5 \mathrm{~cm}$, lebar $=60 \mathrm{~cm}$ dan panjang $=120 \mathrm{~cm}$. Tabung pengolahan digerakan dengan energi kinetik yang bersumber dari angin dilengkapi dengan penyimpanan tenaga (baterai). Komponen lainnya adalah Kincir angin sebagai sumber tenaga penggerak komposter terdiri dari beberapa bagian diantaranya rangka, kincir angin, dan instalasi penggerak. Kincir terbuat dari plat stainless dengan dimensi $60 \mathrm{~mm}$ dan tebal 1,5 mm. Kincir angin akan memutar komposter dengan kecepatan $50 \mathrm{rpm}$. 
Komposter ini dilengkapi pengontrol suhu dalam komposter sehingga apabila mencapai suhu $45 \mathrm{ke}$ atas komposter akan berputar otomatis selama selama 15 menit. Tinggi tiang kincir $5 \mathrm{~m}$. Energi kinetik dari kincir sebagian akan diiubah menjadi energi listrik yang akan tersimpan kedalam baterai. Alat ini juga dilengkapi mesin pencacah terbuat dari bahan plat stainless dan rangka dari besi siku.
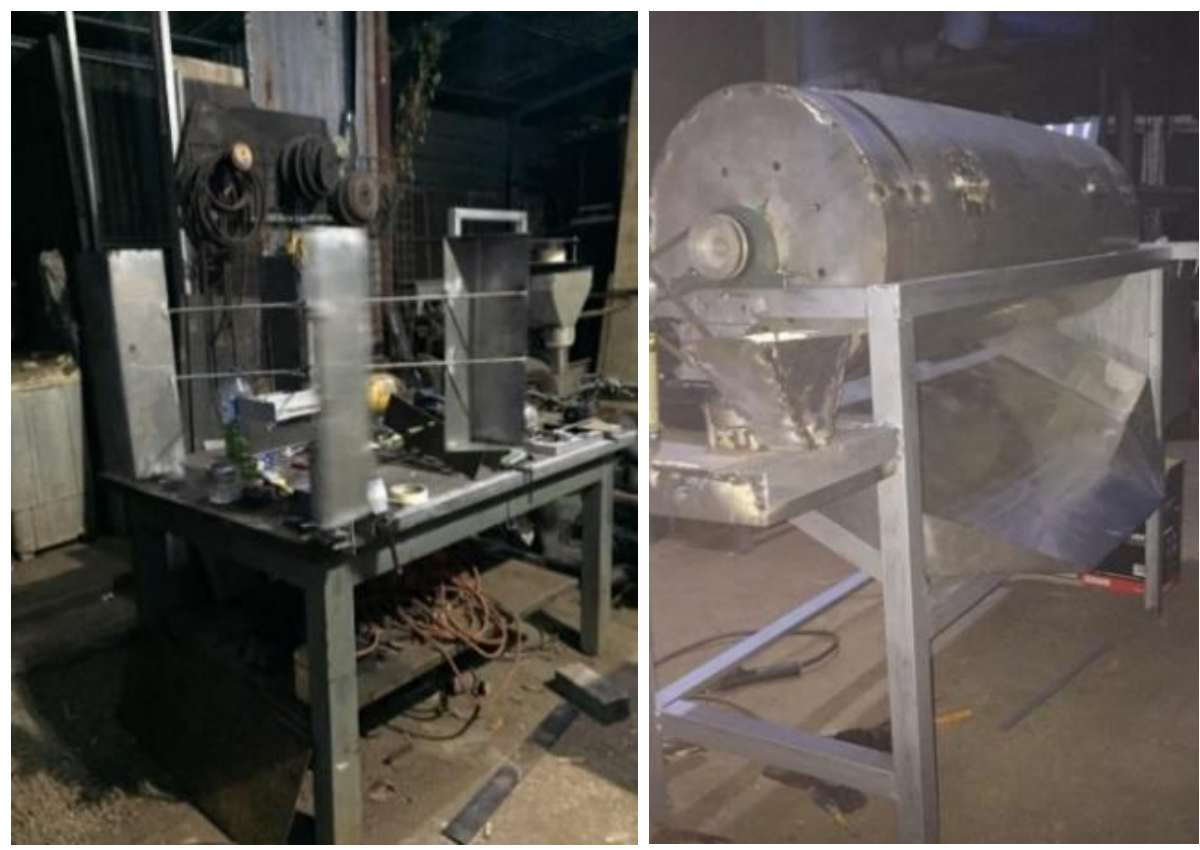

Gambar 4. Pembuatan Alat

\section{Pelatihan SOP Alat dan Praktek Pembuatan Kompos}

Pelatihan SOP alat dilakukan bersama warga agar dapat mengoperasikan alat komposter sesuai dengan SOP.

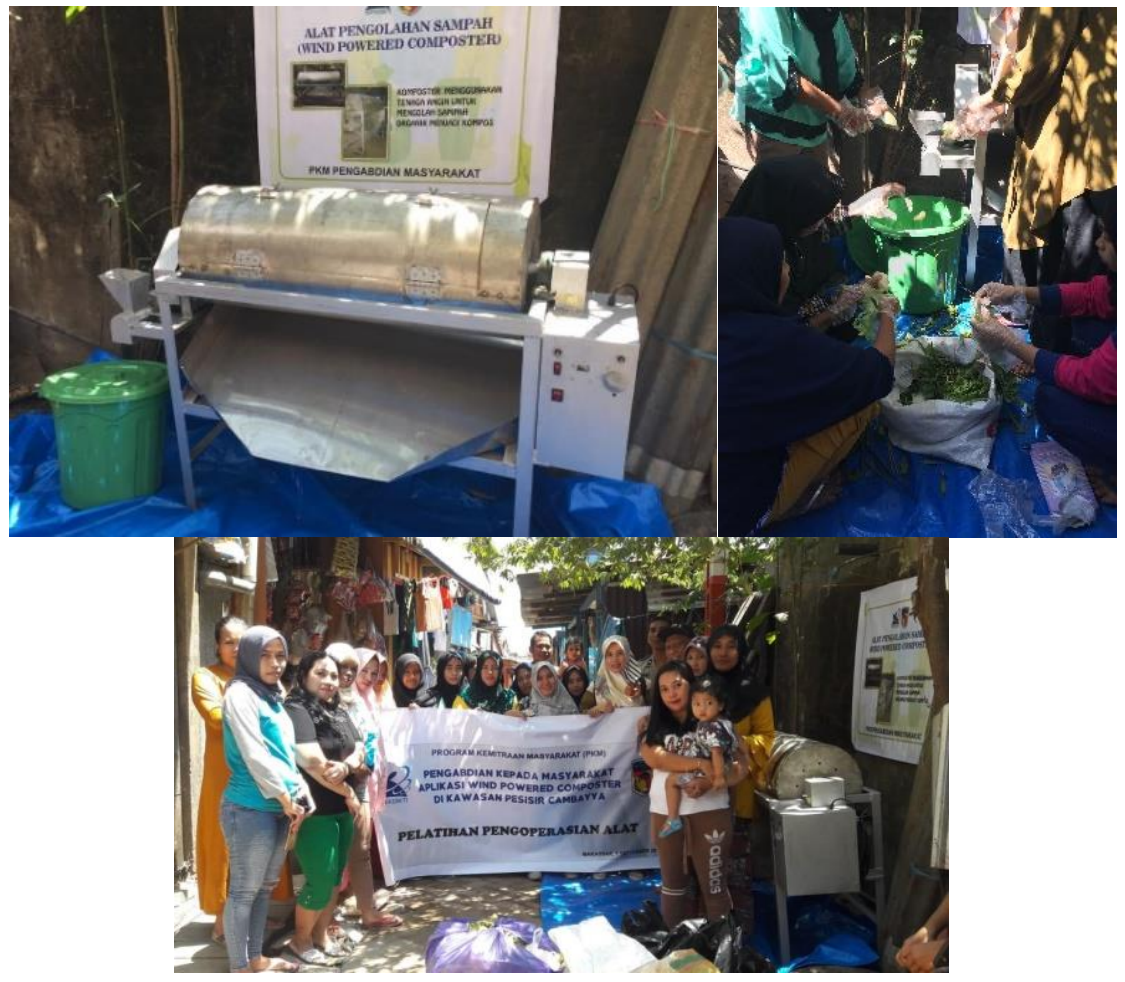

Gambar 5. Pelatihan SOP Komposter

Jurnal Panrita Abdi, 2020, Volume 4, Issue 1. 
Pelatihan SOP alat dilanjutkan dengan praktek pengolahan sampah di lokasi yang dengan beberapa tahapan :

a). Pengumpulan Sampah organik

Pengumpulan sampah organik dilakukan oleh warga ke dalam kantong plastik yang sudah diberikan. Jumlah sampah yang masuk berasal dari 20 rumah tangga yang telah dipilah dengan berat sekitar $48 \mathrm{~kg}$. Sampah organik yang telah dipilah terdiri dari sampah sisa makanan, sampah sayuran, dan kulit buah dan akan diolah menggunakan komposter.

b). Pencacahan Sampah

Pencacahan sampah organik yang dikumpulkan oleh warga menggunakan alat pencacah pada mesin komposter

c). Pemasukan Sampah ke Komposter

Menurut Kaleka (2010) penggunaan bioaktivator merupakan salah satu unsur penting yang mempercepat proses pengomposan. Sampah yang telah dicacah dicampurkan dan dimasukkan ke dalam komposter kemudian di tambahkan kompos jadi sebagai starter, sekam gergaji dan penggunaan larutan EM4 sebagai bioaktivator untuk mempercepat proses pengomposan.



Gambar 6. Pencampuran sampah di komposter

d). Pengadukan Sampah

Pengadukan sampah dilakukan dengan menekan tombol pada komposter sehingga tabung komposter akan berputar.

\section{Panen Kompos}

Proses penguraian bahan organik oleh mikroba dapat mengakibatkan suhu yang cukup tinggi pada tahap awal. Suhu akan turun secara bertahap yang menandakan terjadinya pematangan pada kompos. Kisaran suhu yang ideal untuk komposting adalah $45-70^{\circ}$. Penen kompos dilakukan pada hari ke 10 dengan pengontrolan suhu secara berkala. Pada hari ke 9 suhu mulai kembali normal dan hari ke 10 dilakukan pemanenan bersama warga. Kompos yang sudah jadi menunjukkan warna coklat kehitaman, aroma seperti bau tanah atau bau humus hutan, dan suhu sama dengan suhu lingkungan (SNI, 2004). Setelah kompos dipanen, dilakukan pengayakan untuk menyaring partikel kompos yang halus yang akan dipacking dan kompos yang kasar dimasukkan kembali untuk dijadikan starter. 

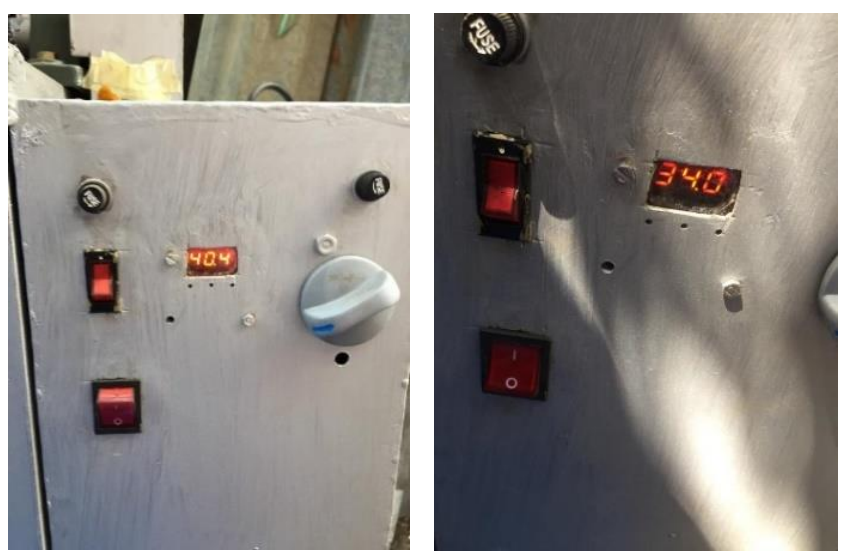

Gambar 7. Pengontrolan suhu secara berkala pada hari ke 4 dan hari ke 8
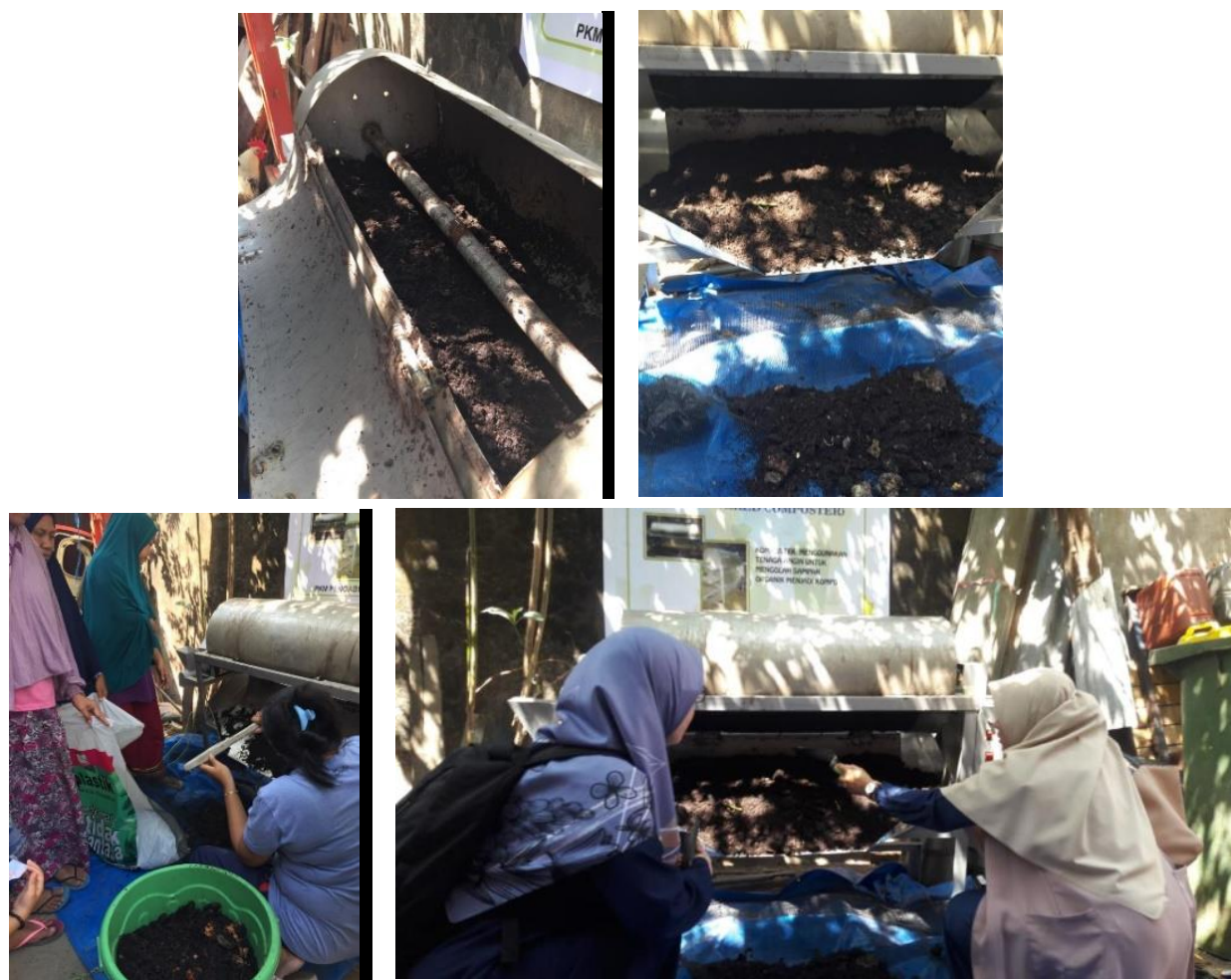

Gambar 8. Panen hasil kompos
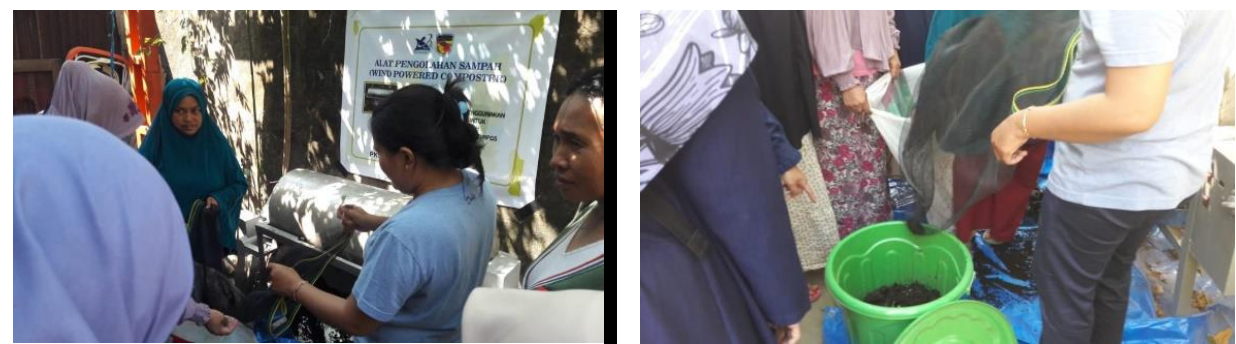

Gambar 9. Pengayakan kompos

\section{Pengemasan Kompos}

Terjadi penyusutan volume/bobot kompos seiring dengan kematangan kompos. Penyusutan kompos sebesar 40\%. Hasil kompos sebelum di ayak mencapai $31 \mathrm{~kg}$. Hasil kompos yang telah diayak dikemas dengan menggunakan plastik dan diberi label bersama dengan warga. Dengan adanya produk kompos ini akan digunakan untuk penghijauan tanaman di lorong pesisir cambayya dan untuk jangka panjang akan dipasarkan. 


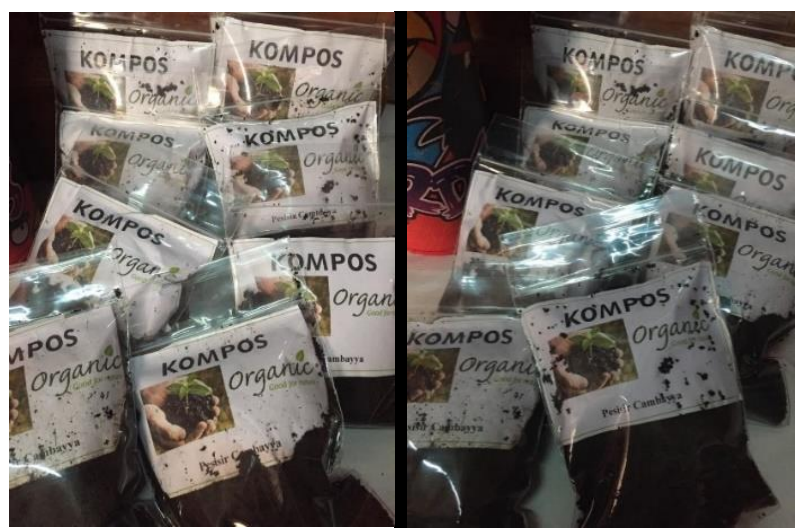

Gambar 10. Packing produk kompos

\section{A. Kegiatan Tahap III : Evaluasi dan Pendampingan}

Kegiatan tahap ini diisi dengan pendampingan dan pemantauan proses pembuatan kompos yang dilakukan warga secara berkala dimulai dari lama waktu pengomposan dan kompos yang dihasilkan apakah telah sesuai dengan standar sari segi bau dan warna sampai dengan proses pengemasan kompos.
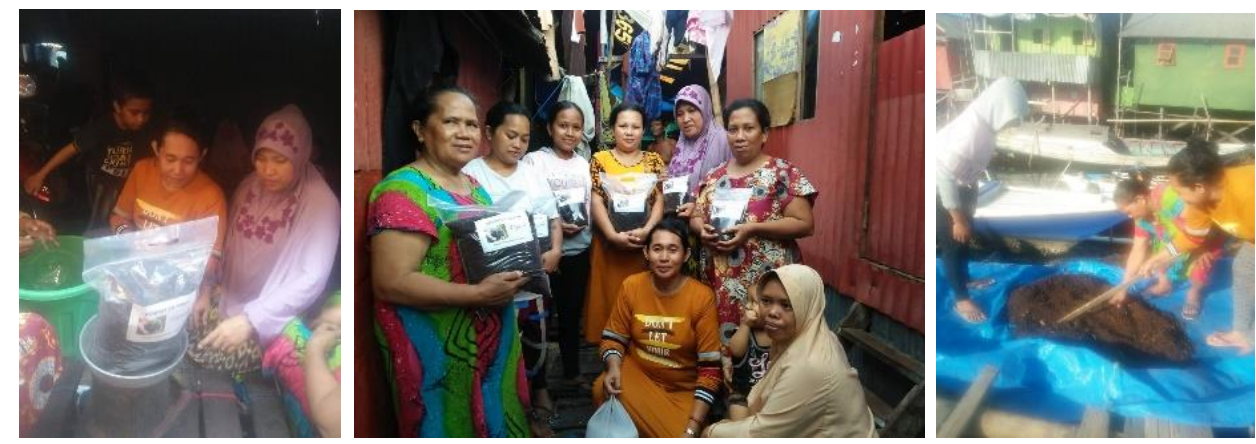

Gambar 11. Pendampingan

\section{B. Keberhasilan Kegiatan}

Keberhasilan kegiatan Pengabdian kepada Masyarakat dapat dilihat dari hasil evaluasi dan indikator keberhasilan. Kesadaran dan pengetahuan masyarakat tentang pemilahan sampah organik dan pengolahan sampah menggunakan alat komposter menjadi semakin meningkat. Indikator keberhasilan penerapan teknologi Wind Powered Composter dilihat dari berhasilnya warga dalam menghasilkan produk kompos. Dari hasil evaluasi terjadi peningkatan kemampuan dalam pengolahan sampah di permukiman pesisir Cambayya menggunakan Wind Powered Composter sebesar 90\%. Sebanyak 10\% warga yang belum memahami tahapan proses pengolahan sampah organik dengan menggunakan teknologi Wind Powered Composter. Hal tersebut dapat diatasi dengan melakukan praktek secara berkelanjutan sehingga warga dapat terlatih dan dapat meningkatkan kemampuannya. Selain itu terjadi pengurangan volume sampah di sekitar lokasi pesisir maksimal sebanyak $60 \mathrm{~kg}$ dalam setiap proses.

\section{Kesimpulan}

Pelaksanaan kegiatan PKM ini menunjukkan bahwa warga telah memiliki pengetahuan dan keterampilan dalam mengolah sampah organik dan mengoperasikan alat Wind Powered Composter. Praktek pembuatan kompos telah menghasilkan produk kompos yang telah dikemas dan dapat digunakan pada penghijauan lorong serta bernilai ekonomi. Selain itu volume produksi sampah di 
sekitar lokasi pesisir telah mengalami pengurangan maksimal sebanyak $60 \mathrm{~kg}$ dalam setiap proses.

\section{Ucapan Terima Kasih}

Penulis menyampaikan terima kasih kepada DPRM Kemenristekdikti, Mitra Ibu-ibu warga RT A pesisir Cambayya, Lurah Cambayya, Universitas Teknologi Sulawesi, Universitas Bosowa, dan Laboran Teknik Mesin Universitas Hasanuddin atas segala bantuan selama PKM ini dilaksanakan.

\section{Referensi}

Anggraini, N. (2011). Aplikasi Teknologi Pengomposan Berbasis Partisipasi Masyarakat. Tesis MST UGM : Yogyakarta

Anggraini, N., \& Ramdiana. (2018). Studi Pengukuran Timbulan Sampah di Kawasan Pesisir Kelurahan Cambayya Kota Makassar. Jurnal Multi Teknik, 13(3), 550-558.

Badan Pusat Statistik. (2017). Kecamatan Ujung Tanah dalam angka. Badan Pusat Statistik Kota Makassar. Makassar.

Djuwendah, E. (2000). Analisis Keragaan Ekonomi dan Kelembagaan Penanganan Sampah Perkotaan di Kotamadya Bandung. Laporan Penelitian, Lembaga Penelitian UNPAD.

Kaleka. (2010). Kompos dari Sampah Rumah Tangga. Jakarta : Delta Media.

Kusdiah, H., Tresna, J., \& Ali, S. A. (2018). IbM Kelompok Usaha Bandeng Segar Tanpa Duri di Kabupaten Pangkep Sulawesi Selatan. Jurnal Panrita Abdi, 2 (1), 55-63.

Lando, A.T., Arifin, A.N., Selintung, M., Sari, K., Djamaluddin, I. \& Carongre, M.A. (2019). Sosialisasi dan Pendampingan Sistem Pengelolaan Sampah Menjadi Kompos Skala Sekolah di SD Inpres Kantisang, Tamalanrea. Jurnal Panrita Abdi, 3(2), 113-124.

Mutaqin, \& Totok, H. (2010). Pengelolaan Sampah Limbah Rumah Tangga dengan Komposter Elektrik Berbasis Komunitas. Jurnal Litbang Sekda Yogyakarta, Vol 2(2).

Rifa'i, M.A., Kudsiah, H., \& Muzdalifah (2017). Alih teknologi produksi benih anemon laut secara aseksual. Jurnal Panrita Abdi, 1(1), 33-39.

Standar Nasional Indonesia. (2004). Spesifikasi Kompos dari Sampah Organik Domestik. SNI : Jakarta

Zubair, A., Mahendra, N.S., \& Asrini. (2011). Studi Karakteristik Sampah Rumah Tangga di Kota Madya Makassar dan Prospek Pengembangannya. Prosiding. UNHAS

Penulis:

Ramdiana, Jurusan Teknik Pengembangan Wilayah dan Kota, Fakultas Teknik, Universitas Muhammadiyah Parepare. E-mail: ramdiana.uts@gmail.com

Nani Anggraini, Jurusan Teknik Lingkungan, Fakultas Teknik, Universitas Bosowa, Makassar. Email: nanianggraini.uts@gmail.com

Sattar Yunus, Jurusan Teknik Mesin, Fakultas Teknik, Universitas Muslim Indonesia, Makassar. Email: sattaryunus@ymail.com

Hadiratul Kudsiah, Departemen Perikanan, Fakultas Perikanan dan Ilmu Kelautan, Universitas Hasanuddin, Makassar. Email: ira.kudsiah@gmail.com

Bagaimana men-sitasi artikel ini:

Ramdiana., Anggraini N., Yunus, S., \& Kudsiah, H. (2020). Aplikasi Wind Powered Composter di Kawasan Pesisir Cambayya Kota Makassar. Jurnal Panrita Abdi, 4 (1), 92 - 102. 